\title{
Jenyffer Nascimento's Epic Poetry of Black Female Empowerment
}

\author{
Jenyffer Nascimento: a Poesia Épica de Empoderamento da Mulher \\ Negra
}

Sarah Ohmer ${ }^{1}$

Submetido em 20 e aprovado em 30 de novembro de 2018.

Quero outro carnaval,/ Dessa vez, sem você. [I want another carnival,/One without you in it.] Jenyffer Nascimento

\begin{abstract}
This article presents results of auto-ethnography, literary analysis, and fieldwork research to answer an underlying, perhaps unresolved, concern, relevant to this dossier: how can we produce a transnational Black Feminist dialogue as transnational between Black Brazilian women and North American Black women, in an ethical manner, while realizing that one may (not ever) be a part of the "carnival without you in it." Fertile Earth/ Terra Fértil tells a long overdue epic story to an audience within the poetry: Black women, family members, other times a Black man, Brazil, white women, or undefined "you". Joy to pain to chaos, sensuality and ritual, stages of grief to empowerment in a poetic ritual of carnivalesque journey from the heart of the Northeast of Brazil in Pernambuco to the underbelly of São Paulo. In We are Rooted Here and They Can't Pulls Us Up, Bristow et al. demonstrate the multi-generational presence and intellectual production of Black women in Canada. Nascimento's epic poetry undoes 500 years of policies that have attempted to silence Black women in Brazil as invisible, unemployed, objectified, infertile (DA SILVA, 2014). Black women's voices echo out of a literary canyon that extends all the way to Canada, a neoliberal rift that keeps Black women out. Each poem analyzed in this article convey challenges relating to Black affect and desire, heteronormativity in the Black Brazilian Movement, and Black women in São Paulo, Brazil, and in the Americas.
\end{abstract}

Keywords: 21st Century Poetry. Cannon. Carnival. Black Movement in Brazil. Neoliberalism. Auto-ethnography. Epic Genre.

Resumo: Este artigo apresenta resultados de autoetnografia, analise literária e pesquisa de campo para responder a uma preocupação subjacente, talvez não resolvida, relevante para este dossiê: como podemos produzir um diálogo transnacional feminino negro entre mulheres negras brasileiras e mulheres negras norte americanas, de forma ética, dandose conta que, de uma maneira ou de outra, é possível nunca ser parte do "carnaval sem você nele". Terra Fértil narra uma história épica há muito esperada por uma audiência dentro da poesia: mulheres negras, membros da família, outras vezes um homem negro, mulheres brancas, um "eu" indefinido. Da alegria para dor, para caos, sensualidade e ritual, estágios de sofrimento a estágios de empoderamento no ritual poético de uma jornada carnavalesca, do coração do nordeste brasileiro, em Pernambuco, ao submundo 
de São Paulo. Em We are Rooted Here and They Can't Pulls Us Up, Bristow et al. demonstram a presença multigeracional e intelectual da produção das mulheres negras no Canadá. A poesia épica de Nascimento desfaz 500 anos de políticas que tentam silenciar a mulher negra como invisível, desempregada, objetificada e infértil (DA SILVA, 2014). As vozes das mulheres negras ecoam para fora do cânone literário que mantém as mulheres negras de fora, por uma brecha que se estende até o Canadá. Cada poema analisado neste artigo implica em desafios relacionados a afeições e desejos e heteronormatização no Movimento Negro Brasileiro e mulheres negras em São Paulo, no Brasil e nas Américas.

Palavras-chave: Cânone. Carnaval. Movimento Negro no Brasil. Neoliberalismo. Autoetnografia. Gênero épico.

\section{Another Carnival, Another Genre of Epic Poetry}

"I want another carnival," claims the poetic voice in Fertile Earth/ Terra Fertil, “one without you in it.” (NASCIMENTO, 2014, p. 59). Jenyffer Nascimento's verse carries a legacy of oppression against Black women and centuries of nation-making attempts to whiten Brazil through, for example, opening doors to European immigrants that were offered more opportunities than Africans and descendants of Africans since the 1800s (BUTLER, 1998). In one verse her poetry talks back to 50 years of policies that have attempted, often successfully, to make Black women infertile, through medication or surgeries without their consent (DA SILVA, 2014, 113). The verse also reminds us of the Carnivals of the African Diaspora, with you, outsiders, in it, with our ancestors and deities honored. In this verse I hear Black women's voices echoing out of a literary canyon, because this is more than the literary cannon, it's a neoliberal rift of national and nationalist literature that keeps Black women out and follows the patriarchal model of the cannon around the world. In Brazil, the literary canyon preserves Black women's representations as domestics, enslaved, insane, illiterate, and unable to write or publish.

"I want another carnival," claims the poetic voice in Fertile Earth/Terra Fertil, "one without you in it." A Carnival without the objectification and erasure of Black women, one without You, racist Brazil, who has given "me," Black Brazilian woman, no time, money, or energy. A Carnival without you, my partner, my lover, my spouse, because the time has come for me to dance on my own, to march, to prance, to write on my own. A Carnival 
without you, Black Brazilian movement, who continues to make me invisible, and without you, too, Black Brazilian male writers, who scoff at my "almost-poetry" and fidget when you hear about yourself, about sex, about abuse, in our spoken word events. A Carnival without You — self-hate, internalized oppression -- because I'd rather spend my energy on loving myself, dressing up, dressing down. It's hot, the music sounds great, and this is the season to praise myself in a Carnival without You, self-hating Me.

In this verse, I also see Nascimento denounce a Black movement that tried but did not really attempt to include their sisters or assist in publishing their work, and speak against a 21 st century literary market that still puts Luso-African and British writers on the shelves, featured in festivals as the Annual Brazilian Literature Festival in Paraty, a chic cultural event that features all white Brazilian writers, with the exception of Paulo Lins (who does not self-identify as Black) and Conceição Evaristo (who does self-identify as a Black Brazilian woman). Meanwhile, Black women writers from Brazil sell books at booths they can't afford, in a corner reserved for one hour of a weekend long festival, in the streets, or with minimal public funding for Black women founded collectives like the Mjiba, founded by the Elizandra sisters in 2013, to support literature projects and cultural events. The Mjiba Collective funded Jenyffer Nascimento's book with the help of municipal, state, and federal grants for cultural and diversity initiatives supported by the Dilma Roussef Administration. ${ }^{2}$ Collectives like Mjiba are facing difficult times with the 2016 government changes at the municipal, state and federal levels that have cut public funding for women, Black Brazilians and diversity, and culture in general.

At spoken word events or "Saraus" in São Paulo and other cities, poets like Jenyffer Nascimento are stars. Young adults whisper to each other when she arrives, "oh look there's Jenyffer!", and organizers feel special if they make an appearance at their spoken word event. These poets sell out books in months, autographing for young Brazilians of all races - but mostly Black - and mostly lower socioeconomic class, many of them girls and women living in the outskirts of São Paulo. Audiences crave their voice and having Black women telling their stories on stage, though none of them appear to earn particular socio-economic mobility. The stardom status is associated with their poetry and creativity. This is part of the stage of another carnival, one without You in it. 
Fertile Earth/ Terra Fertil anchors the positionality of a lower-class Back woman in Brazil, sometimes in the rural, coastal, laid back, folkloric and nostalgic Northeast of Brazil, known for its historically black communities and poverty, and most times in the landlocked, cold, grey, wet São Paulo, suffocating yet inspiring and vibrant megalopolis in the Southeast of Brazil, infamous for its omnipresent racism, police violence against Black Brazilians, nightlife, and booming Black culture and Black women’s activism. The poetic voices tell a long overdue epic story to an audience within the poetry, sometimes made up of Black women, or family members, other times a Black man, other times Brazil, other times white women, or just, "you," undefined. We read, hear, feel what she wants, what she needs, what she desires, what she dreams, why she is fed up by and what inspires her as the poet uses affection in her poetry.

Fertile Earth/ Terra Fertil dances in a Carnival without "you" in it, and shows her readers what the party looks like, from joy to pain to chaos, sensuality and ritual, on walks through the stages of grief to recovery and empowerment in this ritualistic book. Terra Fertile/ Fertil Earth offers a poetic ritual of carnival from a Black Brazilian woman's perspective, in a Black Brazilian female epic genre where one young woman represented through the poetic voices of individual women and men, journeying from one place to the next, not across countries because, let's face it, it's not affordable, but the poetic voices walk through multiple sceneries, from the heart of the Northeast of Brazil in Pernambuco to the underbelly of São Paulo. The journeys of the poetic voices parallel the Anzaldúaesque nepantlera spiritual and literary journeys, the in-between exploration while straddling multiple cultures (Northeast and Southeast Brazil), languages (Yoruba and Brazilian Portuguese, intuitive and literary, etc.), race and sexuality. She looks for her keys, loses her keys, finds herself, loses herself...meets women, men, delves deep into the ruptured womb of "Brazil with a W of Whore," an underworld that lies not below, but is very much bubbling up to and visible at the surface of the city, in a Black Brazilian female epic genre. This book of epic poetry outlines what it takes to want, to imagine, to orchestrate and to have another Carnival, one without You in it.

Each poem analyzed in this chapter directs me, the literary critic, to make inferences on the literary scene in São Paulo, Black affect and desire, heteronormativity in 
the Black Brazilian Movement, among other issues pertaining to women of colors in São Paulo, Brazil, and in the Americas; with an underlying, perhaps unresolved, concern: how to produce an ethical dialogue as an outsider, with Black Brazilian women, and resolve in an ethical manner, that one may (not ever) be a part of the "carnival without you in it."

At the same time, and more concretely, this book of poetry based on being real, does not offer up a Carnival that is a place to just dance and be pretty. Terra Fertil/Fertile Earth serves as a manual to survive and thrive. Terra Fertil/Fertile Earth shows what and where are the keys to Black womanhood in Brazil, through the epic quest, and understand why are they so hard to find, and why do they not open any doors,,

\section{First Encounters with Jenyffer Nascimento: Poet, mother, lover...}

Jenyffer Nascimento is part of the latest generation of Black Brazilian women writers in São Paulo, who recite in spoken word events in the periphery of São Paulo and put together their poems into books of poetry, usually self-published. Nascimento comes from Pernambuco, the northeast of Brazil, and lives with her mother and her son in a working class neighborhood in the South of São Paulo. She has a full time job in the education sector, self-defines as a Black Brazilian and identifies with Black women authors from throughout the Americas and the African Diaspora. She claims one of the foundational São Paulo "Saraus" — or spoken word venues-- the Southside of São Paulo "Sarau Coperifa," as a creative home where a lot of her poetry was written.

When I first met Jenyffer Nascimento, I was the only literary critic at the "Black Women Writing in São Paulo" event, in a public library in the central middle class neighborhood of Pinheiros, in March 2015. And I was also the only non-Brazilian.

It was raining and dark by 3p.m., or so it felt; it was Fall in March and cold and wet and dreary. Here we were, in an auditorium, in a day-long event about "Escrita Mulher Negra," Black Women's Writing, four panels of participants whom I would call the literary rock stars of São Paulo (all featured in prior chapters of this book): Miriam Alves, Raquel Almeida, Tiely Queen, Jenyffer Nascimento, Elizandra Souza, with even an appearance from one of the few Black women recognized as a writer, Conceição Evaristo, an award-winning internationally recognized author, also recognized in Brazil 
before she dies. Evaristo is the exception, and she reminds her audiences of this and that Black Brazilian women writers did not make the rules. Their antecedent Carolina Maria de Jesus died poor, with three books published, only to be recognized nationally on the 50th anniversary of her death, in 2015.

I showed up early, a half hour late, everyone else showed up late, one to two hours late. In São Paulo we take "CP time" to the next level! With the traffic and magnitude of the city, it's not a stereotype as much as a reality, it takes time to get places, and I mean that literature and figuratively.

I first met Jenyffer Nascimento at one event, in a public library, in São Paulo. Jenyffer Nascimento, I found out later, over a cold beer, came in a cab and we joked about it and I complimented her, "hey, girl, if you can afford it go for it". In many ways, she had made it. A full tie and secure job in education, a beautiful and well-educated son, a functional relationship with his father, who was willing to be a part of his life, living with her mom while she saved up for her own place, her first book published in the Fall of 2014. Terra Fertil/Fertile Earth was an apt title for her successes.

I presented my first impressions of the literature of women that stood in the audience, all writers included in the previous chapters: Miriam Alves, Esmeralda Ribeiro, Raquel Almeida. I was wide eyed, they were too, and I was frightened and humbled by this task, hoping I would, against literary criticism practices, with Global South Feminist practice of an ethical dialogue (MOHANTY, 2003, p. 108) and Black feminist practice of distinctive methodology (HILL COLLINS, 2000, p. xii), hoping I would make them proud, make them heard, honor their work as an outsider, without essentializing or misreading. Jenyffer appreciated my approach, and she noted she hadn't yet spoken with literary critics study about her and others' literature yet. And she definitely had not met a Black woman literary critic from the United States coming out to a spoken word event out in the hood getting to know the scene, you know, "for real".

That rainy day in March I finally had her book in my hands. I had heard about it, about her, and missed her book launch party but I was with Raquel Almeida and Miriam Alves that night, and Raquel showed a whatsapp or facebook status with her book cover on it: "Essa nega é foda... [This sister is bad ass]." And I didn't need to hear it twice. Red 
lipstick, mega afro, son in one hand and book in the other, an assertive "I don't give a fuck" tone and deep awareness of where she had been, where her people had been, both white and black, her humility tore up the room where she started talking honestly and vulnerably about her poetry: "I did not call myself a poet for a long time, I was a poetess, who was I to write poetry. And I still get surprised of the life that this book has on its own, it's become its own entity, and folks meet the book, and get to know it, and I'm stunned. Like, someone asked why is there so much sex in this? Well honey there's a lot of sex in my life! But it's not about that. But it's what this person sees. I don't know...."

She was surprised when, a few weeks later, I made it all the way out to her neighborhood, the far south of São Paulo, the last stop on the newest subway line, my cell did not work and neither did hers, I waited for almost an hour and someone came up to me, a complete stranger, asking if I was Jeny's friend. He was a mixed race Brazilian man, possibly mid-thirties, wearing a green Adidas Brazil green and yellow jacket, had passed by me a few times, beautiful kinky hair and kind eyes scanning strangers' faces, when he asked timidly, “um... Are you...?” I think he said my name, or Jenyffer's name, I can't remember, but I did say yes, my shoulders relaxed and my face lit up with that big smile I give old friends, kiss on the cheek and hug, as if we'd known each other for years. I hopped into his old red Fiat, and he and his wife chatted on our way to the infamous Sarau Coperifa, one of the original spoken word groups of São Paulo.

Saraus, or spoken word groups, have been popping up all over São Paulo since the 1990s. Each Sarau began with a group of poets who gathered at a neighborhood bar, and the earliest Saraus, such as Sarau Coperifa, have grown to become institutions in the outskirts of the city, where young adults find their voice and a place to become their own, in a city that oppresses and suffocates.

The couple asked about how I knew Jeny, and I got to know they were close friends of hers who had been going to the Sarau Coperifa for years and were involved in a documentary on Saraus in São Paulo. I explained I had met Jeny at the Escrita Mulher Negra event on Black Women Writers in São Paulo, and when we met a few weeks later over beers, she invited me to attend Coperifa to understand where her poetry was coming from and to get to know the real São Paulo. 
The husband, sitting in the passenger seat, responded: "Only Jeny could set this up - no phone, no number, I asked her how am I going to recognize this girl, she said oh, you'll know. And she was right." I wasn't sure what to feel, but my body relaxed among friends, after an hour and a half of not being quite sure where I was headed or if I would find it, and another hour waiting at a metro station staring at strangers, looking for Jenyffer!

We drove up a few small streets, in what seemed like a working class, quiet neighborhood, two story-homes and lots of cars parked along the sidewalks. The homes looked asleep, so quiet I wondered where the famous Sarau might be. We pulled up to a corner restaurant packed and overflowing with a younger crowd. Mixed races, many different hairstyles from big afros to dreadlocks, straight blonde and black hair, mixed ages from the teens to the sixties and kids running too, playing with white balloons. They were going to release white balloons with favorite verses of poetry in them. Most people had clear glass mugs of beer in hand, and a cigarette.

And there was Jeny, they said. Being the social butterfly that she is, she was chatting it up with a friend, clearly at home, she seemed to know a lot of people there. Lighting up a cigarette when she saw me, I was just in time for her reading, she said, after this cigarette. “Ah! Giiiiiiiirl! You made it!” she squealed in Portuguese. We caught up briefly as people shuffled back inside, for the next round of spoken word. Jeny walked up to the mic, cheered on by the crowd, and complete silence set in when she took a breath, and started to read, humbly, her face changed, almost, scared, naked, vulnerable. A poet in the making.

At these events I could only get as real as I could, aware of my lighter skin tone, privilege as a U.S. academic, with a fellowship, a foreign accent that would come out when I spoke Portuguese, an experience of world travel and clearly in that honeymoon phase of cultural adaptation, that "everything is so great here" cultural adaptation honeymoon phase... While I was reminded how damn hard life was here, I had a choice to go home at any time. And I would be reminded, and become very aware of this, and be made aware of it, too. That we were different. It does not come easy, to understand, and co-exist, in a Carnival without You. 


\section{Sex, Love and Carnival: On Black Affect and Desire}

"Do Jeito Que Vier" features a poetic voice with an ambiguous gender, at the doorstep of the epic journey, with a Nascimentoesque mermaid serenade. ${ }^{3}$ Then "Lua cheia," a female poetic voice, goes on the epic journey of claiming desire and Black womanhood, and into the underworld of São Paulo, with her she-wolf pack. Each poem presents a different take on Black Affect and desire, and contributes to the image of what Sex and Love look and feel like in a Carnival without You, as we roam the streets of São Paulo in the epic journey to find the keys to (and other keys away from) Black womanhood...

Do Jeito Que Vier/ Come as You are

Te quero suja, vinda da rua / I want you dirty, coming off of the streets

Com suor, poluição e cansaço / With that sweat, pollution and fatigue

Sem dar tempo pra água ou café. / No time for water or coffee

Te quero nua / I want you naked Sem crise com depilação / no need for a wax Pés descalços, esmaltes descascados. / Barefeet, chipped nailpolish Sim, eu reparo e acho bonito / Yes, I make it work and find it beautiful

Seu jeito largado / This disheveled look of yours Meninice aos quase trinta. / A barely thirty year old teen.

Te quero solta / I want you loose Vivendo o desapego. / Living being turned off. Eu sei, você já disse um milhão de vezes / I know, you already said it, a million times now,

Que não quer casar. / You won’t marry me. Mas eu vejo, seu olho brilha / But I see, your eye twinkles Quando te espero na porta / When I wait for you by the door,

Sem compromisso (você acha)/ No plans (or so you think) Te faço janta, arroz com brócolis/ I make you dinner, rice and peas Bife à milanesa e cerveja barata./ Fried steak and cheap beer.

Te quero em brasa/ I want you on fire Sangue fervendo/ Blood boiling Mordendo, arranhando / Biting, clawing Gemendo alto / Moaning loud Sem ligar pra vizinhança. / No mind for the neighbors Acendendo filtro vermelho / Lighting up a red filter Depois da transa. / After sex.

Te quero doce/ I want you sweet 
Mel e jabuticaba, / Honey and jabuticaba ${ }^{4}$

Escapando saudade / Avoiding being missed

Arriscando carinho / Risking affection

Deixando de lado a postura fria/ Setting aside the cold shoulder

De quem viveu amores gris./ Of someone who had tough loves.

Primaveira minha/ My little Spring

Fica, por favor./ Please, stay a little while.

É possível, sim, é possível. / This is possible, yes, it is, possible.

(NASCIMENTO, 2014, p. 44-45)

Is this what love looks like in a Carnival without You? The poetic voice in this poem is not the positionality of a Black woman, or is it? It's a lover, whose gender and race are left to be determined. The references to food (rice and broccoli, the equivalent to rice and peas, rice and beans, in other cultures of the African Diaspora), along with references to honey and "jabuticaba," gastronomical elements of Black Brazilian culture, hint at the poetic voice's blackness. Honey is a recurring image in poems by Black women in Brazil. Jabuticaba, a large grape with a thick purple skin, and a tender pink flesh inside, connotes sensuality, pulp, quenching thirst, sweet flavor. This is a sensuous ode from a mermaid to "you," inviting their lover and audience inside this loving home, while the reader becomes a participant, a voyeur, an intimate third party to two Black Brazilians taking risks in affection, hot sex, a good meal, and non-heteronormative partnership.

The poem ends addressing the lover as "my little Spring/ primavera minha" setting up a Black woman lover as birth, spring. The shift from "te quero suja/I want you dirty" to "te quero doce/ I want you sweet" and the use of adjectives that would otherwise be objectifying, here are empowering. "Come as you are" cultivates black affect, desire, care, affection, with the only sound in the poem being "you" "moaning loudly," with no regard for her neighbors. The repetition of "I want you" builds up the erotic climax of the poem, purposefully, with adjectives going from dirty, to naked, to loose, to on fire, and to sweet. The poem ends addressing the lover as "my little Spring/ primavera minha" setting up a Black woman lover as fertile, fecund, full of poetic possibilities in all of her dirty, sweaty, hairy, naked, on fire sweet moaning glory. 


\section{Carnivalesque with a Black Samba Twist}

Carnaval, or Mardi Gras in Brazil, has a deep tradition of folklore, spirituality, in parallel with a long history of oppressing Black women especially in the Northeast of Brazil, place of origin of Jenyffer Nascimento, poet, mother, activist, hip hop head, educator. Carnival was originally a way for Africans to practice religious rituals, strategize and train for rebellions, after they had been forced to migrate to Brazil in the global economy of slavery, starting in the 1500s. Through the centuries, Carnival was made illegal, then appropriated for tourism and whitened - the original Black folklore was washed away, Black dancers and musicians forbidden to participate-then made to fit the Brazilian myth of racial democracy, as a cultural product of the melting pot of the races, with mixed race women at the forefront, while Africans who had crossed the Atlantic in the Middle Passage made their own Carnival in Brazil.

In some aspects, Carnival objectifies women, prioritizes mixed race "mulattas" over dark-skinned women, ${ }^{5}$ is a time of increased prostitution, trafficking, rape, while some Samba stages feature their Black queens prominently, center stage; "look at our beautiful Black queen!" some will say, of their lead dancer at the Samba school of Mangueira, a historically-Black working class neighborhood in Rio de Janeiro. It has also become a corrupt contest, a championship where Samba schools compete for costume design, song lyrics, musical composition, and overall performance, at "Sambodromes" or Samba Stadiums across the country, where cities invest millions in a three-day staging for travelers who will pay thousands of dollars to attend in person, while a majority of citizens look for potable water or new homes to replace ones that have been taken down (PERRY, 2013, p. 43).

Carnival, from Black women's perspectives, is also about love, going all out, having a good time, drinking beer, making love, kissing strangers, ownership of our bodies. Carnival can also reinforce the reality of poverty: who gets to dance, who has to stay home, who begs on the street; socioeconomic differences become strikingly visible. Carnival from Black women's perspectives is this and much more.

In this chapter, I invite you to walk through, dance, scream, dress up and dress down, in Jenyffer Nascimento Fertile Earth of a Carnival. As "you" has multiple 
meanings, so do Black Brazilian women's experiences. Let us listen to and learn from a Black Brazilian female poetic voice from the Northeast, living in the Southeast of Brazil, and place her realities and expectations to the forefront, the center stage. Let's learn as feel a beautiful Black queen's dance of epic poetry.

\section{Sex, Love and Carnival: On Black Affect and Desire}

In Tornar-se Negro: as vicissitudes da identidade do negro em ascensão social/ Becoming Black: the vicissitude of the identity of Black Brazilians in Social Mobilit, Neusa Santos Souza explains how the violence of racism, on a psychological level, affects Black Brazilians' desire and pleasure, including erotic and sexual pleasure. The ideal of whiteness has affected Black Brazilians, she argues, to recreate a constant cycle of emotional abandonment, frustration, and pain, when it comes to love and desire.

Brazil promotes an ideal of whiteness culturally and socially, and economically supports it. The ideal of whiteness affects body image, Santos Souza argues, and desire. When it comes to Black Brazilians, the psychic economy becomes based on pain rather than desire, a constant loss due to not being enough, not having enough, because of the stigmatization of the color of the skin, nappy hair, facial features and bodies. Black Brazilian desire is amputated by society; she states (SANTOS SOUZA, 1983, p. 8-11). But this does not mean Blacks do not recuperate and cultivate desire and affection for each other.

In turn, a lot of the work around Black subjectification and representation (by Blacks) in Brazil deals with the violence of the white Ideal, the replies to this pain, and how Black Brazilians attempt to scab over what has been bleeding - they undo the representation of their bodies as wounded, scared, unloving of themselves and needing a white Ideal to feel sexy and beautiful — an unhealthy ideal that harks back to colonial racial stratification (SANTOS SOUZA, p. 10). Neusa Santos Souza dedicates her entire book to this process, from a psychological perspective and Jenyffer Nascimento tackles this issue throughout her book of poems, as subject and poet-intellectual, Terra Fertil/ Fertile Earth, with a title potently associated with the womb and fertility, revolves around the pleasure of thinking and the thinking of pleasure, the pleasure of wanting, desiring 
and being desired by Black men and women, as a Black Brazilian woman.

In "Full Moon," the poetic voice is ambiguously female, on the hunt, her senses are sharpened by the moon, and sexual desire is associated with the streets, urban outings, and ani-men, specifically one man she characterizes as savage, in a good way:

Lua cheia / Full Moon Instintos primitivos / Primitive instincts

Boca salivando / Mouth watering Lua cheia aponta: / With the full moon says one thing only: --À caça. / --off to the hunt. Fêmea no cio / Female in heat Rastreio pegadas / Reconheço suas marcas. / I recognize these marks. Essa fera é bicho-homem./ This beast is a man-imal. Aprendi na madrugada,/ I learned early on, A Lidar com bicho solto./ How to deal with animals running wild.

Demarcar território/ Mark the territory Não adianta./ Don't wait. [adianta?]

Cobra criada/ Trained [cobra?] serpents

Sabe bem onde pisa./ Know where you set foot.

Se for pra ser/ If it were to be É melhor não deixar rastro./ It would be best not to leave it.

$\mathrm{Na}$ selva urbana / In the urban rainforest

Me camuflo / I wear camouflage

Me metamorfoseio/ I metamorphose

Me faço de inocente/ I play innocent Mas não nego a intenção. / But I don’t deny intent. Minha natureza carnivora/ My carnivorous nature Me conduz a presas indefesas./ Leads me to defenseless prey.

Circuno o ambiente/

Preparo o bote:/ I get the boat ready: --Aceita um gole?/ --how about we score?

Sorriso / A smile

Diálogos breves/ Brief back and forth

O Corpo fala. / The body says it all. Ação pede reação. / From action, reaction. Simbioso./ I symbiose. Bicho-homem é ágil/ The ani-man is agile De indefeso para ofensivo./ From helpless to agressive. Selvagem, sabe devorar como ninguém. / Savage, it knows to devour like none other.

Emana dessa espécie/ From this species emanate Onomatopeias de todos os tipos. / Onomatopeias of all types. O devir é o silêncio. / Silence is duty. Dispenso despedidas./ I bid adieu.

Gosto mesmo é de vender sonhos./ I like selling dreams.

Volte pro seu bando/ He returns to his clan Vou reencontrar minha alcateia./ I go find my she-wolf pack 
Qualquer lua cheia dessas/ One of these full moons A gente se encontra por aí/ We will see each other, around. Na Selva de Pedras./ In the Concrete Jungle.

This playful poem rewrites a casual encounter in a bar. Nascimento takes the "savage" stereotype, and the wounded/ugly traits, usually associated to Black Brazilians in literature, and make them her own: "Primitive instincts, mouth watering, the full moon says one thing only_ off to the hunt." It helps to imagine Jenyffer Nascimento reading the poem, as many of her poems were created in spoken word weekly round ups, and she recites with a balance of fierceness and playful humor. The poem sets up an assertive tone, with the use of verbs in the command form and her knowledge ("I learned at dawn... know where you set foot," etc.), as well as a sense of humor that sisters can get, in the audience: "off to the hunt...female in heat...I learned early on how to deal with these man-imals running wild." (wink wink!) The poetic voice's assertion is relatable: "I play innocent/ But I don't deny intent./ My carnivorous nature/ Leads me to defenseless [manimal] prey....I bid adieu. I like selling dreams." The game of tag at a bar as a young Black woman, in charge, in sync, in symbiosis with a brother, earns more value in the context that Jenyffer Nascimento wrote. Though the literary / spoken word scene was opening up to the periphery of São Paulo, traditionally made up of male writers, still writing about Black women, objectifying, owning the pen, the desire, and reacting openly and negatively when Black women would go up to the mic to share their two cents in verse about sex, love, ownership of their bodies. This poem inverts the roles of subject-object within $21^{\text {st }}$ century Black Brazilian São Paulo spoken word poetry. The poetic voice, female in heat, knowledgeable, symbioses with an ani-man, agile and on the offensive, she is carnivorous, he knows to devour like none other, and "From this species emanate onomatopeias of all types." Another poetry can arise out of symbiosis among genders, the living together of unlike organisms, a lyrical connection, a Black-woman-affect-based poetics integrated and undoing the patriarchic heteronormative Black literary scene.

Perhaps now is not the time, and the poetic voice bids adieu, in the hope that one day, on a full moon, male and female poets can see eye to eye, and in the meantime she will keep writing poetry, and enjoy it, and keep having casual encounters, and enjoy it: "I 
like selling dreams./ He returns to his clan,/ I go find my she-wolf pack/ One of these full moons/ We will see each other/ In the Concrete Jungle."

A Carnival without You.

\section{Bibliography}

BUTLER, Kim D. Freedoms Given, Freedoms Won: Afro-Brazilians in Post-Abolition São Paulo and Salvador. New Brunswick: Rutgers University Press. 1998.

DA SILVA, Cidinha. Introduction. Africanidades e Relações Raciais: Insumos para Políticas Públicas na Área do Livro, Leitura, Literatura e Bibliotecas no Brasil. Brasília, DF, Brazil: Fundação Cultural, Palmares, 2014, p. 13-23.

2013.

. Racismo no Brasil e afetos correlatos. Porto Alegre, Brazil: Conversê Edições,

HILL COLLINS, Patricia. Black Feminist Thought: Knowledge, Consciousness and the Politics of Empowerment. New York, NY: Routledge, 2000.

MOHANTY, Chandra Talpade. Feminism without Borders: Decolonizing Theory, Practicing Solidarity. Durham \& London: Duke University Press, 2003.

NASCIMENTO, Jenyffer Sylva do. Terra Fértil. São Paulo, Brazil: Ed. do Autor com Coletivo Mjiba, 2014.

PERRY, Keisha Khan. Black Women Against the Land Grab. Minneapolis, MN: University of Minnesotta Press, 2013.

SANTOS SOUZA, Neusa. Tornar-se negro. As vicissitudes do Negro Brasileiro em Ascensão Social. Rio de Janeiro, Brazil: Edições Graal, 1983.

\section{Notes}

${ }^{1}$ All translation by the author of this essay.

${ }^{2}$ The Dilma administration was the successor of leftist President Lula who began several programs to assist Brazilians of African descent and lower class Brazilians; in 2016 a parliamentary coup ousted Dilma Roussef and all of the social assistance programs were cut and São Paulo's new mayor also cut all programs that supported diversity and culture in the city. One latest example was the current mayor's project to use public funding to paint over graffiti murals throughout the city, including those next to the São Paulo's equivalent of Central Park, Ibirapuera Park, a well-known landmark that attracted tourists and graffiti artists around the world, who would take photos of the graffiti from a pedestrian overpass overlooking miles of graffiti along São Paulo's central highway.

${ }^{3}$ It is worth noting the parallel with symbology of mermaid in gender/sexuality especially in regards to nonheteronormativity.

${ }^{4}$ Grape from a Brazilian myrtaceae tree native to São Paulo and Minas Gerais states. The word is originally Tupi-Guaraní, an indigenous language spoken in Brazil.

${ }_{5}^{5}$ See the Brazilian broadcast channel Globo's selection of the face of Carnival in 2016. Available at g1.globo. com/carnaval/2016/ 